\title{
FAKTOR-FAKTOR YANG MEMPENGARUHI SIKAP PASANGAN USIA SUBUR (PUS) MELAKUKAN SKRINING KANKER SERVIKS METODE IVA DI WILAYAH KERJA PUSKESMAS KOTA WILAYAH UTARA KOTA KEDIRI
}

\author{
Ira Titisari, Triatmi Andri Yanuarini, Sumy Dwi Antono \\ Prodi Kebidanan Kediri Jl.KH.Wakhid Hasyim 64 B Kediri
}

Email: iratitisari@ymail.com

\begin{abstract}
The number of cases of cervical cancer in Kediri continues to increase, in 2004: 165 cases, 2005: 170 cases and 2006: 175 cases. Cumulative target achievement in 2009-2013 amounted to $12.16 \%$. Coverage is still far below the annual target of Kediri has stepped fifth year that is equal to $80 \%$.The purpose of this study was to analyze the factors that influence women's attitudes Couples of Childbearing Age for cervical cancer screening methods IVA in Puskesmas City area north of Kediri. Design research is analytic observational cross-sectional approach. The population is all Couples of Childbearing Age women aged 30-50 years in the region of Northern Regional Health Center in the amount of 400 samples of 50 people were taken by cluster random sampling. The analysis used bivariate correlation analysis Chi-square and multivariate analysis using multiple logistic regression. The result of this research is there is a relationship between knowledge ( $\mathrm{p}$-value $=0.00)$, resources $(\mathrm{p}$-value $=0.001)$, family support $(p$-value $=0.001)$ and personal experiences $(p$-value $=0.016)$ with the attitude of women Couples of Childbearing Age did IVA cervical cancer screening method in Puskesmas City area north of Kediri and the factors that influence attitudes Couples of Childbearing Age woman doing IVA cervical cancer screening method in Puskesmas City area north of the town of Kediri is knowledge ( $\mathrm{p}$ value $=0.003$ ) with a big influence 2,176.It can be concluded that the factors that influence women's attitudes Couples of Childbearing Age for cervical cancer screening methods IVA in Puskesmas City area north of Kediri is knowledge.
\end{abstract}

Keywords: WomenCouples of Childbearing Age, Attitude, IVA

\section{Latar Belakang}

Kanker serviks merupakan masalah kesehatan yang penting bagi wanita di seluruh dunia. Pada tahun 2001 kanker serviks merupakan jenis kanker ke dua yang paling umum pada perempuan dan dialami oleh lebih dari 1,4 juta perempuan di seluruh dunia. Pada tahun 2000 setiap tahun lebih dari 460.000 kasus terjadi dan sekitar 231.000 perempuan meninggal karena penyakit kanker serviks. Di Indonesia menurut data dari Sistim Informasi Rumah Sakit (SIRS) tahun 2007 kanker serviks menempati urutan ke dua setelah kanker payudara, untuk pasien rawat inap $(11,78 \%)$ dan pasien rawat jalan $(17,00 \%)$. Jumlah kasus kanker serviks di
Kota Kediri terus mengalami peningkatan, pada tahun 2004 : 165 kasus, tahun 2005 : 170 kasus dan tahun 2006 : 175 kasus.

Menurut ketua umum Yayasan Kanker Indonesia (YKI) pada tahun 2007 di Indonesia diperkirakan ada 15.000 penderita baru per tahun dan 8000 penderita meninggal setiap tahun. Karena itu deteksi dini dan pengobatan pra kanker serviks perlu menjadi prioritas. Menurut data di RSUD dr.Soetomo Surabaya pada tahun 2009 setiap hari sedikitnya ada 8-10 kasus baru kanker serviks. Setiap tahun rata-rata ditemukan kasus baru kanker serviks sebanyak 300-350 orang. Dari kasus tersebut sekitar 60-80\% penderita yang datang ke Rumah Sakit sudah dalam 
kondisi stadium lanjut. Tingkat penyembuhan kanker serviks pada stadium I kemungkinan dapat disembuhkan $90 \%$, stadium II kemungkinan dapat disembuhkan $70 \%$, stadium III kemungkinan dapat disembuhkan $30 \%$ dan stadium IV kemungkinan dapat disembuhkan $10 \%$.

Sejak tahun 1977 telah dilakukan upaya diagnosis dini kanker serviks yaitu dengan menggunakan Pap Smear. Masalah Pap Smear di Indonesia banyak menemui kendala yang dikaitkan dengan akurasi (cara dan saat pengambilan, fiksasi, pengeringan, pengecatan dan kemampuan interpretasi pemeriksa); tehnik pengambilan yang kurang praktis karena hanya dapat dikerjakan oleh tenaga terlatih; sumber daya manusia yang terbatas; geografi (wilayah Indonesia sangat luas dan terdiri dari beribu-ribu pulau, serta masih sulitnya komunikasi dan transportasi antar wilayah ) dan sikap wanita yang selayaknya menjalani skrining (enggan untuk diperiksa karena ketidaktahuan, perasaan malu, perasaan takut dan adanya faktor biaya ).

Sejak tahun 2004 di Indonesia dikenal adanya metode baru untuk skrining awal kanker serviks yaitu dengan metode IVA (Inspeksi Visual dengan Asam asetat). Pemeriksaan IVA merupakan pemeriksaan pada mulut rahim (serviks) dengan mengoleskan asam asetat 3-5 \% pada serviks dan mengamati selama 1 - 2 menit adanya plak putih yang menebal (epithel acetowhite). IVA merupakan suatu tes yang secara visual digunakan untuk mendeteksi lesi pra ganas pada serviks. IVA dapat diterapkan pada berbagai situasi dan kondisi, karena tidak memerlukan pemeriksaan laboratorium dan hasilnya akan cepat didapat. Terapi dapat langsung dilakukan bersama dengan pemeriksaan.Tes ini mudah dilaksanakan dan dapat dilaksanakan oleh dokter umum, bidan dan paramedis yang telah dilatih pemeriksaan IVA. Sejak Oktober 2004 sampai September 2006 diadakan Proyek Demonstrasi untuk skrining kanker serviks metode IVA di Bandung, Jakarta dan Bali.
Pada tahun 2007 dikembangkan proyek percontohan (pilot project) pengendalian kanker serviks oleh Kementerian Kesehatan Republik Indonesia bekerjasama dengan Lembaga Swadaya Masyarakat (LSM), Organisasi Profesi, Perguruan Tinggi, Lintas Sektor dan masyarakat. Proyek percontohan tersebut dikembangkan di 4 wilayah yaitu Sumatera Utara, Kalimantan Selatan, Sulawesi Utara dan Jawa Timur. Proyek percontohan pengendalian kanker serviks di Jawa Timur pertama kali dilaksanakan di Kabupaten Gresik pada tahun 2007 (dana APBN), kemudian dikembangkan ke Kabupaten Malang pada tahun 2008 (dana APBN), dikembangkan lagi ke Kota Kediri dan Kabupaten Trenggalek pada tahun 2009 (dana APBD I).

Secara admnistratif Kota Kediri membawahi 3 wilayah Kecamatan , 46 Kelurahan, 9 puskesmas dan 26 Puskesmas Pembantu (Pustu). Jumlah penduduk Kota Kediri pada tahun 2010 sebanyak 269.989 jiwa.

Pada tahun 2009 - 2010 Dinas Kesehatan Kota Kediri mengirim tenaga dokter dan bidan untuk mengikuti pelatihan skrining kanker serviks metode IVA, yang terdiri dari 27 orang (19\% dari 141 total jumlah dokter dan bidan di semua / 9 Puskesmas Kota Kediri), 5 orang dari Dinas Kesehatan Kota Kediri dan 5 orang dari RSUD Gambiran Kota Kediri. Pada bulan November 2010 Dinas Kesehatan Kota Kediri menyelenggarakan kegiatan on the job training tentang skrining kanker serviks metode IVA yang pesertanya adalah semua dokter umum dan bidan di Puskesmas dan Pustu wilayah Dinas Kesehatan Kota Kediri yang belum mengikuti pelatihan yaitu sebanyak 114 orang. On the job training dilaksanakan dengan metode ceramah, tanya jawab, simulasi dengan model dan praktek lapangan.

Di Kota Kediri pelayanan untuk skrining kanker serviks metode IVA dilaksanakan oleh sebagian petugas yang sudah mengikuti pelatihan dan sebagian 
petugas yang mengikuti $O n$ the job training $(31,5 \%)$. Pelayanan dilaksanakan di semua Puskesmas (9 Puskesmas), sebagian Pustu (13 Pustu) dan sebagian Bidan Praktek Swasta. Untuk Pustu tidak semua melayani pemeriksaan IVA, dari 26 Pustu di Kota Kediri yang melayani IVA hanya 13 Pustu (50 \%), hal ini dikarenakan masih terbatasnya meja ginekologi dan lampu halogen yang digunakan untuk pemeriksaan skrining kanker serviks metode IVA. Bidan Praktek Swasta (BPS) di Kota Kediri hanya sebagian saja yang melayani pemeriksaan IVA, yaitu bidan yang bekerja di Puskesmas / Pustu / RSUD Gambiran / Dinas Kesehatan Kota Kediri yang sudah mengikuti pelatihan atau mendapat sosialisasi melalui kegiatan on the job training yang diselenggarakan oleh Dinkes Kota Kediri. Untuk pemeriksaan IVA di Puskesmas / Pustu pasien dikenakan biaya Rp. 20.000.

Program skrining kanker serviks metode IVA sudah dilaksanakan sejak akhir tahun 2009, dengan kelompok sasaran yaitu wanita usia 30-50 tahun (yang sudah melakukan hubungan seksual). Target yang ditentukan oleh Kementerian Kesehatan Republik Indonesia adalah $80 \%$ yang minimal dicapai dalam 5 tahun. Untuk cakupan kumulatif program skrining kanker serviks metode IVA di Kota Kediri pada tahun 2009 adalah $1,36 \%$ (target 16 $\%$ ), tahun 2010 adalah 5,06\% (target $32 \%$ ) dan tahun 2011 adalah 7,96\% (target 48 $\%$ ), tahun 2012 adalah 10,56\% (target 64 $\%$ ) dan tahun 2013 adalah 12,16\% (target $80 \%)$.

Untuk pencapaian pemeriksaan IVA tahun 2013 per Puskesmas adalah sebagai berikut Puskesmas Campurejo 1,59 \%, Puskesmas Kota wilayah utara 0,31 \%, Puskesmas Balowerti 1,71 \%, Puskesmas Kota wilayah selatan $0,87 \%$, Puskesmas Sukorame 1,19 \%, Puskesmas Pesantren II 0,42 \%, Puskesmas Pesantren I 1,57 \%, Puskesmas Mrican 1,17 \% dan Puskesmas Ngletih 4,11\%.

Upaya yang sudah dilaksanakan oleh Dinas Kesehatan Kota Kediri guna menunjang keberhasilan program skrining kanker serviks metode IVA yaitu pada saat memperingati Hari Kesehatan Nasional mengadakan pemeriksaan IVA masal terhadap 200 wanita usia subur pada kelompok sasaran dan mengadakan sosialisasi tentang skrining kanker serviks metode IVA pada kader-kader kesehatan.

Dasar kebijakan yang digunakan sebagai pedoman pelaksanaan program skrining kanker serviks metode IVA adalah Keputusan Menteri Kesehatan Republik Indonesia No 796 / Menkes / SK / VII / 2010 tentang pedoman teknis pengendalian kanker payudara dan kanker leher rahim di Indonesia.

Berdasarkan survey pendahuluan terhadap 10 orang wanita usia subur didapatkan bahwa semua belum pernah melakukan tes IVA, 6 orang belum tahu tentang tes IVA dan 4 orang sudah tahu tentang tes IVA tapi takut untuk melakukakan tes.

Berdasarkan permasalahan tersebut dan pentingnya pelaksanaan skrining kanker serviks metode IVA maka peneliti tertarik untuk mengetahui faktor-faktor yang mempengaruhi sikap wanita usia subur melakukan skrining kanker serviks metode IVA di wilayah kerja Puskesmas Kota wilayah utara Kota Kediri.

\section{METODE PENELITIAN Populasi}

Populasi dalam penelitian ini adalah semua wanita PUS usia 30 - 50 tahun di desa Kemasan di wilayah kerja Puskesmas Kota Wilayah Utara yaitu sebesar 400 orang

\section{Sampel}

Sampel dalam penelitian ini adalah sebagian wanita PUS usia 30 - 50 tahun di wilayah kerja Puskesmas Kota Wilayah Utara.

\section{Sampling}

Dalam penelitian ini menggunakan teknik sampling Cluster Random Sampling.Dalam penelitian ini sebagai 
Cluster adalah Desa yang ada di wilayah kerja Puskesmas Kota Wilayah Utara. Dari masing-masing Cluster dipilih secara proporsional (30\%), sehingga didapatkan 3 Desa yang terpilih yaitu Desa Kemasan, Desa Setono Gedong dan Desa Pakelan.

\section{Kriteria Sampel}

a. Kriteria Inklusi

Kriteria inklusi adalah karakteristik umum subjek penelitian dari suatu populasi target yang terjangkau yang akan diteliti. (Nursalam, 2003)

1) Bersedia menjadi responden

2) Dapat membaca dan menulis

b. Kriteria eksklusi
Adalah menghilangkan
atau mengeluarkan subyek yang memenuhi kriteria inkusi dari suatu studi karena berbagai sebab (Nursalam, 2003).

1) Penderita kanker serviks

\section{Besar Sampel}

Menurut Notoatmodjo (2010), apabila besar populasi lebih kecil dari 10.000 besar sampel dapat dihitung dengan menggunakan rumus sebagai berikut:

$$
\begin{aligned}
n & =\frac{\mathrm{N}}{1+\mathrm{N}(\mathrm{d})^{2}} \\
\mathrm{n} & =\frac{\mathrm{N}}{1+\mathrm{N}(\mathrm{d})^{2}} \\
\mathrm{n} & =\frac{3879}{1+3879(0,15)^{2}} \\
\mathrm{n} & =50
\end{aligned}
$$

Dari perhitungan jumlah sampel didapatkan 50 PUS. Dari 50 PUS tersebut tersebar di 3 Desa, ditentukan cara pengambilannya dengan metode proportional random sampling dengan rumus :

$$
\mathrm{ni}=\frac{\mathrm{Ni}}{\mathrm{N}} \mathrm{n}
$$

Keterangan :

$\mathrm{ni}=$ Jumlah sampel tiap Desa $\mathrm{n}=$ jumlah sampel seluruhnya

$\mathrm{Ni}=$ jumlah populasi

$\mathrm{N}=$ Jumlah populasi seluruhnya

Sehingga besar sampel tiap wilayah puskesmas dapat diihat dalam tabel 3.1

Tabel 3.1 Jumlah Sampel wanita PUS

\begin{tabular}{|l|l|l|l|l|}
\hline No & Desa & $\begin{array}{l}\text { Jumlah } \\
\text { PUS }\end{array}$ & $\begin{array}{l}\text { Perban } \\
\text { dingan }\end{array}$ & Sampel \\
\hline 1. & Kemasan & 272 & $\begin{array}{l}272 / 816 \times \\
50\end{array}$ & 17 \\
\hline 2. & $\begin{array}{l}\text { Setono } \\
\text { Gedong }\end{array}$ & 160 & $\begin{array}{l}160 / 816 \times \\
50\end{array}$ & 10 \\
\hline 3. & Pakelan & 384 & $\begin{array}{l}384 / 816 \times \\
50\end{array}$ & 23 \\
\hline & Jumlah & 816 & & 50 \\
\hline
\end{tabular}

\section{Analisa Data}

a) Analisis Univariat

Analisis univariat digunakan untuk memperoleh gambaran dari masingmasing variabel yang meliputi pengetahuan, media masa (sumber informasi), dukungan keluarga, pengalaman dan sikap wanita PUS melakukan skrining kanker serviks metode IVA.

b) Analisis Bivariat

Analisis bivariat adalah analisis yang digunakan untuk melihat hubungan dua variabel yang berhubungan atau berkorelasi dimaksudkan untuk mengetahui hubungan masing-masing variabel bebas. Adapun analisis yang digunakan dalam penelitian ini adalah analisis korelasi Chi-Square untuk mendapatkan hubungan bermakna.

Dalam menentukan hubungan yang bermakna antara variabel bebas dengan terikat menggunakan p-value yang dibandingkan dengan tingkat kesalahan yang digunakan yaitu $5 \%$ atau 0,05 , jika $\mathrm{p} \leq 0,05$ maka Ho ditolak yang berarti ada hubungan yang signifikan antara variabel bebas dengan variabel terikat dan jika $\mathrm{p}>0,05$ maka Ho diterima yang berarti tidak ada hubungan yang signifikan antara variabel bebas dengan variabel terikat. Selanjutnya variabel bebas yang mempunyai hubungan bermakna dengan 
variabel terikat dimasukkan dalam analisis multivariat.

c) Analisis Multivariat

Analisis multivariat untuk mengetahui hubungan secara bersamasama antara variabel bebas dan variabel terikat. Dalam rangka mencari variabel bebas yang paling berhubungan dengan variabel terikat dengan menggunakan uji statistik regresi logistik berganda.

Interpretasi data terhadap uji kemaknaan koefisien regresi bila p-value $\leq 0,05$ maka variabel bebas tersebut ditetapkan sebagai variabel terikat.

\section{HASIL PENELITIAN}

\section{Analisis univariat}

Pengetahuan wanita PUS tentang skrining kanker serviks metode IVA. Adapun distribusi frekuensi pengetahuan responden tentang skrining kanker serviks metode IVA dapat dilihat pada tabel 4.1

Tabel 4.1. Distribusi frekuensi pengetahuan responden

\begin{tabular}{|l|l|l|l|}
\hline No & Pengetahuan & Frekuensi & Prosentase \\
\hline 1 & Kurang & 18 & $36 \%$ \\
2 & Cukup & 19 & $38 \%$ \\
3 & Tinggi & 13 & $26 \%$ \\
\hline & Total & 50 & 100 \\
\hline
\end{tabular}

Berdasarkan tabel 4.1 diatas dapat dilihat bahwa sebagian besar responden 19 orang (38\%) berpengetahuan cukup.

Pengetahuan responden diperoleh dari tenaga kesehatan, televisi, majalah, internet dan radio, namun sebagian besar diperoleh dari tenaga kesehatan. Bidan di wilayah kerja Puskesmas Kota wilayah Utara sering mengadakan penyuluhan ke masyarakat tentang skrining kanker serviks metode IVA yaitu pada saat kegiatan posyandu dan pelayanan di Puskesmas Pembantu.

Pada saat ini kesadaran masyarakat akan pentingnya kesehatan sangat tinggi. Masyarakat selalu mencari informasiinformasi tentang seputar kesehatan di media massa baik di televisi, majalah, Koran, radio dan internet.

Hal ini didukung pula oleh tingkat pendidikan responden yang sebagian besar yaitu 39 orang $(78 \%)$ adalah Sekolah
Menengah Atas (SMA) atau sederajat. Dengan tingkat pendidikan SMA atau sederajat tersebut responden mudah untuk menerima informasi baik dari petugas kesehatan maupun dari media massa.

Menurut Notoatmodjo (2003), pengetahuan adalah berasal dari bahasa tahu, yang berarti seseorang yang mempunyai pengalaman dan cakrawala tertentu, bisa melalui pendidikan formal atau informal. Termasuk hal-hal yang diketahui seseorang tentang dirinya, tingkah lakunya dan keadaan disekitarnya. Pengetahuan adalah hasil dari tahu, dan ini terjadi setelah orang melakukan penginderaan terhadap suatu objek tertentu. Penginderaan terjadi melalui pancaindera manusia, yaitu penglihatan, pendengaran, penciuman, rasa dan raba. Sebagian besar pengetahuan manusia diperolah melalui penglihatan dan pendengaran.

2. Media massa (sumber informasi) yang diperoleh wanita PUS tentang skrining kanker serviks metode IVA

Adapun distribusi frekuensi sumber informasi yang diperoleh responden tentang skrining kanker serviks metode IVA dapat dilihat pada tabel 4.2

Tabel 4.2. Distribusi frekuensi sumber informasi yang diperoleh responden

\begin{tabular}{|l|l|l|l|}
\hline No & $\begin{array}{l}\text { Sumber } \\
\text { informasi }\end{array}$ & Frekuensi & Prosentase \\
\hline 1 & Ada & 44 & $88 \%$ \\
2 & Tidak ada & 6 & $12 \%$ \\
\hline & Total & 50 & 100 \\
\hline
\end{tabular}

Berdasarkan tabel 4.2 diatas dapat dilihat bahwa sebagian besar responden 44 (88\%) sudah pernah mendapat informasi tentang skrining kanker serviks metode IVA.

Sumber informasi tentang skrining kanker serviks metode IVA diperoleh dari petugas kesehatan, televisi, majalah, internet dan radio. Sebagian besar sumber informasi dari responden didapatkan dari tenaga kesehatan. Di Puskesmas Kota Wilayah Utara setiap kegiatan posyandu dan pelayanan di Puskesmas pembantu, Pos Kesehatan Kelurahan bidan selalu 
memberikan penyuluhan tentang skrining kanker serviks metode IVA.

Selain itu sosialisasi tentang skrining kanker serviks saat ini sudah banyak ditemukan di media massa baik di televisi, majalah, koran dan internet. Semua lapisan masyarakat saat ini sudah dengan mudah untuk mengakses sumber informasi melalui media massa. Sehingga masyarakat sudah tidak asing lagi dengan skrining kanker serviks metode IVA tersebut.

Hal ini didukung pula oleh sebagian besar resonden yaitu 30 orang (60\%) bekerja sebagai ibu rumah tangga sehingga mempunyai banyak waktu luang untuk mengakses informasi tentang skrining kanker serviks metode IVA melaui media massa baik melaui televisi, majalah, Koran, radio dan internet.

Ini sesuai pendapat Heryanto,N (2002) bahwa sebagai sarana komunikasi, media massa seperti televisi, radio, surat kabar, majalah dan lain-lain mempunyai pengaruh dalam pembentukan opini dan kepercayaan orang. Media masa membawa pula pesan sugesti yang mengarahkan opini seseorang.

3. Dukungan keluarga wanita PUS untuk melakukan skrining kanker serviks metode IVA

Adapun distribusi frekuensi dukungan keluarga responden untuk melakukan skrining kanker serviks metode IVA dapat dilihat pada tabel 4.3

Tabel 4.3. Distribusi frekuensi dukungan keluarga responden

\begin{tabular}{|l|l|l|l|}
\hline $\mathrm{N}$ & Duku & Frekuensi & Prosentase \\
$\mathrm{o}$ & ngan keluarga & & \\
\hline 1 & $\begin{array}{l}\text { Mendukung } \\
\text { Tidak }\end{array}$ & 26 & $52 \%$ \\
2 & $\begin{array}{l}\text { mendukung } \\
24\end{array}$ & $48 \%$ \\
\hline & Total & 50 & 100 \\
\hline
\end{tabular}

Berdasarkan tabel 4.3 diatas dapat dilihat bahwa sebagian besar responden 26 (52\%) mendapat dukungan dari keluarga untuk melakukan skrining kanker serviks metode IVA.

Dukungan keluarga yang dimaksud disini adalah dukungan yang diberikan dari orang-orang terdekat yaitu suami, anak, orang tua, saudara, teman dekat, tetangga, teman kerja, dan guru. Dukungan orang terdekat sangat besar artinya dalam membentuk sikap sesorang. Dukungan yang positif akan membentuk sikap yang positif dan dukungan yang negatif akan membentuk sikap yang negatif pula.

Hal ini didukung pula dengan tingkat pendidikan masyarakat, kondisi social ekonomi dan kesadaran masyarakat terhadap kesehatan saat ini sudah semakin baik sehingga mudah sekali untuk memberikan dukungan yang positif bagi responden untuk melakukan skrining kanker serviks metode IVA.

Ini sesuai pendapat Heryanto,N (2002) bahwa orang lain disekitar kita merupakan salah satu diantara komponen sosial yang dapat mempengaruhi sikap. Seseorang yang dianggap penting, seseorang yang diharapkan persetujuannya bagi setiap gerak-tindak dan pendapat, seseorang yang tidak ingin dikecewakan, atau seseorang yang berarti khusus bagi kita, akan banyak mempengaruhi pembentukan sikap kita terhadap sesuatu.

4. Pengalaman pribadi wanita PUS untuk melakukan skrining kanker serviks metode IVA

Adapun distribusi frekuensi pengalaman responden tentang skrining kanker serviks metode IVA dapat dilihat pada tabel 4.4

Tabel 4.4. Distribusi frekuensi pengalaman responden

\begin{tabular}{|l|l|l|l|}
\hline No & Pengalaman & Frekuensi & Prosentase \\
\hline 1 & $\begin{array}{l}\text { Berpengalaman } \\
\text { Tidak } \\
\text { berpengalaman }\end{array}$ & 11 & $22 \%$ \\
\hline & Total & 50 & $78 \%$ \\
\hline
\end{tabular}

Berdasarkan tabel 4.4 diatas dapat dilihat bahwa sebagian besar responden 39 (78 \%) tidak berpengalaman tentang skrining kanker serviks metode IVA.

Sebagian besar responden masih belum pernah mempunyai pengalaman melakukan skrining kanker serviks metode IVA maupun metode Tes Papsmear sebelumnya. Di masyarakat umum skrining kanker serviks masih dipandang sebelah mata, banyak masyarakat yang belum sadar pentingnya skrining kanker serviks sejak 
awal. Sehingga banyak kasus kanker serviks yang ditemukan sudah dalam stadium lanjut dan untuk kemungkinan kesembuhan sangat kecil. Jika kanker serviks ditemukan sejak stadium dini, maka tingkat kesembuhanya sangat tinggi.

Skrining kanker serviks metode IVA tergolong metode untuk skrining kanker serviks yang baru. Sebelumnya metode skrining kanker serviks menggunakan tes papsmear. Pelayanan untuk tes papsmear hanya ada di tempat-tempat tertentu saja yang mempunyai tenaga terlatih untuk melakukan tes papsmear. Sehingga masyarakat banyak yang enggan untuk melakukan tes papsmear. Selain tempat pelayanannya terbatas, biayanya juga lebih mahal dan hasilnya tidak dapat langsung didapat, harus menunggu 2-3 bulan, karena analisis tes pap smear harus dikirim ke lab patologi anatomi di Surabaya.

Ini sesuai pendapat Heryanto,N (2002) bahwa apa yang kita alami akan mempengaruhi penghayatan terhadap stimulus. Tanggapan akan menjadi dasar terbentuknya sikap. Untuk dapat mempunyai tanggapan dan penghayatan, seseorang harus mempunyai pengalaman yang berkaitan dengan objek psikologis. Apakah penghayatan itu akan membentuk sikap positif atau negatif akan tergantung pada berbagai faktor lain.

\section{Analisis bivariat}

Analisis bivariat adalah analisis yang digunakan untuk melihat hubungan dua variabel yang berhubungan atau berkorelasi dimaksudkan untuk mengetahui hubungan masing-masing variabel bebas. Adapun analisis yang digunakan dalam penelitian ini adalah analisis korelasi Chi-Square untuk mendapatkan hubungan bermakna.

a. Hubungan antara pengetahuan dengan dengan sikap wanita PUS melakukan skrining kanker serviks metode IVA

Pembuktian hipotesis adanya hubungan antara pengetahuan dengan sikap wanita PUS melakukan skrining kanker serviks metode IVA, dilakukan uji hubungan dengan uji korelasi Chi-Square. Hasil uji korelasi didapatkan nilap $\mathrm{p}=0,001$, dimana nilai $\mathrm{p}<0,05$ yang menunjukkan ada hubungan antara pengetahuan dengan sikap wanita PUS melakukan skrining kanker serviks metode IVA.

Tabel 4.5. Tabel silang hubungan pengetahuan dengan sikap wanita PUS melakukan skrining kanker serviks metode IVA

\begin{tabular}{|l|l|l|l|l|l|}
\hline N & Sikap & \multicolumn{2}{|l|}{ Pengetahuan } & \multicolumn{2}{l|}{ Total } \\
\cline { 3 - 6 } o & & Kurang & Cukup & Baik & \\
\hline 1 & Negatif & 16 & 9 & 1 & 26 \\
\hline 2 & Positif & 2 & 10 & 12 & 24 \\
\hline & Total & 18 & 19 & 13 & 50 \\
\hline
\end{tabular}

Dari tabel 4.5 diatas dapat dilihat bahwa responden yang mempunyai pengetahuan yang baik tentang skrining kanker serviks metode IVA cenderung mempunyai sikap yang positif dalam hal skrining kanker serviks metode IVA.

Responden yang sudah mempunyai pengetahuan tentang skrining kanker serviks metode IVA sebagian besar mempunyai sikap yang positif terhadap skrining kanker serviks metode IVA. Karena memang banyak sekali keunggulan dari skrining kanker serviks metode IVA diantaranya adalah biayanya murah, dapat dilakukan di fasilitas kesehatan dengan peralatan yang terbatas, dapat dilakukan oleh semua tenaga kesehatan yang sudah mendapat pelatihan atau sosialisasi tentang tes IVA, hasilnya langsung bisa didapat, tehniknya sederhana dan jika ada kelainan dapat langsung diobati saat itu juga.

Pengetahuan merupakan salah satu faktor yang membentuk sikap seseorang. Pengetahuan tentang skrining kanker serviks metode IVA diperoleh responden melalui pendidikan informal yaitu dari penyuluhan yang dilakukan oleh petugas kesehatan yaitu bidan di wilayah kerja Puskesmas Kota Wilayah Utara.

Menurut Notoatmodjo (2003), pengetahuan adalah berasal dari bahasa tahu, yang berarti seseorang yang mempunyai pengalaman dan cakrawala tertentu, bisa melalui pendidikan formal atau informal. Termasuk hal-hal yang 
diketahui seseorang tentang dirinya, tingkah lakunya dan keadaan disekitarnya. Pengetahuan adalah hasil dari tahu, dan ini terjadi setelah orang melakukan penginderaan terhadap suatu objek tertentu. Penginderaan terjadi melalui pancaindera manusia, yaitu pengelihatan, pendengaran, penciuman, rasa dan raba. Sebagian besar pengetahuan manusia diperolah melalui penglihatan dan pendengaran.

b. Hubungan antara media massa (sumber informasi) dengan sikap wanita PUS melakukan skrining kanker serviks metode IVA

Pembuktian hipotesis adanya hubungan antara media massa (sumber informasi) dengan sikap wanita PUS melakukan skrining kanker serviks metode IVA, dilakukan uji hubungan dengan uji korelasi Chi-Square. Hasil uji korelasi didapatkan nilap $\mathrm{p}=0,001$, dimana nilai $\mathrm{p}<0,05$ yang menunjukkan ada hubungan antara media massa (sumber informasi) dengan sikap wanita PUS melakukan skrining kanker serviks metode IVA.

Tabel 4.6. Tabel silang hubungan media massa (sumber informasi) dengan sikap wanita PUS melakukan skrining kanker serviks metode IVA

\begin{tabular}{|c|c|c|c|c|}
\hline \multirow[t]{2}{*}{$\mathrm{N}$} & \multirow[t]{2}{*}{ Sikap } & \multicolumn{2}{|c|}{ Sumber informasi } & \multirow[t]{2}{*}{ Total } \\
\hline & & Tidak ada & Ada & \\
\hline 1 & Negatif & 6 & 20 & 26 \\
\hline 2 & Positif & 0 & 24 & 24 \\
\hline & Total & 6 & 44 & 50 \\
\hline
\end{tabular}

Dari tabel 4.6 diatas dapat dilihat bahwa responden yang memiliki sikap positif semua telah mendapat informasi tentang skrining kanker serviks metode IVA.

Informasi tentang skrining kanker serviks yang diperoleh responden baik dari petugas kesehatan (bidan), televisi, majalah, internet, dan radio menjadi landasan terbentuknya sikap responden tentang skrining kanker serviks metode IVA. Sebagian besar responden mendapat informasi tentang skrining kanker serviks metode IVA dari penyuluhan yang dilakukan oleh tenaga kesehatan yaitu bidan di wilayah kerja Puskesmas Kota Wilayah Utara.

Dalam pandangan masyarakat seorang bidan sangat disegani, dihormati dan dipercaya. Demikian halnya dengan bidan di wilayah kerja Puskesmas Kota Wilayah Utara ini, sehingga setiap informasi yang diberikan oleh bidan kepada masyarakat dapat memberikan sugesti yang positif bagi responden yang menjadi dasar terbentuknya sikap responden yang positif pula yang dalam hal ini adalah sikap responde untuk melakukan skrining kanker serviks metode IVA.

Ini sesuai dengan pendapat Heryanto $\mathrm{N}$ (2002) bahwa adanya informasi baru memberikan landasan kognitif bagi terbentuknya sikap terhadap hal tersebut. Pesan sugesti yang dibawa oleh informasi tersebut apabila cukup kuat akan memberikan dasar afektif dalam menilai sesuatu hal sehingga terbentuk arah sikap tertentu.

c. Hubungan antara dukungan keluarga dengan dengan sikap wanita PUS melakukan skrining kanker serviks metode IVA

Pembuktian hipotesis adanya hubungan antara dukungan keluarga dengan sikap wanita PUS melakukan skrining kanker serviks metode IVA, dilakukan uji hubungan dengan uji korelasi Chi-Square. Hasil uji korelasi didapatkan nilap $\mathrm{p}=$ 0,001, dimana nilai $\mathrm{p}<0,05$ yang menunjukkan ada hubungan antara dukungan keluarga dengan sikap wanita PUS melakukan skrining kanker serviks metode IVA.

Tabel 4.7. Tabel silang hubungan dukungan keluarga dengan sikap wanita PUS melakukan skrining kanker serviks metode IVA

\begin{tabular}{|c|l|c|c|c|}
\hline \multirow{2}{*}{$\begin{array}{c}\text { N } \\
\text { o }\end{array}$} & Sikap & \multicolumn{2}{|c|}{ Dukungan keluarga } & Total \\
\cline { 3 - 4 } & $\begin{array}{c}\text { Tidak mendu } \\
\text { kung }\end{array}$ & $\begin{array}{c}\text { Mendu } \\
\text { kung }\end{array}$ & \\
\hline 1 & Negatif & 19 & 7 & 26 \\
\hline 2 & Positif & 5 & 19 & 24 \\
\hline & Total & 24 & 26 & 50 \\
\hline
\end{tabular}


Dari tabel 4.7 diatas dapat dilihat bahwa responden yang mendapat dukungan dari keluarga cenderung mempunyai sikap yang positif terhadap skrining kanker serviks metode IVA.

Keluarga merupakan hal yang sangat berarti bagi responden, sehingga dukungan dari keluarga dapat memberikan sugesti positif bagi responden. Dukungan keluarga baik dari suami, orang tua, tetangga, teman, saudara, anak sangat besar pengaruhnya terhadap pembentukan sikap responden yang dalam hal ini adalah sikap untuk melakukan skrining kanker serviks metode IVA. Dukungan yang diberikan bisa dalam bentuk materiil dan non materii. Dukungan materiil dapat berupa uang untuk biaya skrining kanker serviks metode IVA. Sedangkan dukungan non materiil dapat berupa persetujuan, support untuk melakukan skrining kanker serviks metode IVA.

Hal ini sesuai pendapat Azwar,S (2008) bahwa orang lain disekitar kita merupakan salah satu diantara komponen sosial yang dapat mempengaruhi sikap. Seseorang yang dianggap penting, seseorang yang diharapkan persetujuannya bagi setiap gerak-tindak dan pendapat, seseorang yang tidak ingin dikecewakan, atau seseorang yang berarti khusus bagi kita, akan banyak mempengaruhi pembentukan sikap kita terhadap sesuatu. Diantara orang yang dianggap penting adalah orang tua, orang yang status sosialnya lebih tinggi, teman sebaya, teman dekat, guru, teman kerja, isteri atau suami dan lain-lain. Pada umumnya individu cenderung mempunyai sikap yang konformis dengan sikap orang yang dianggap penting. Kecenderungan ini dimotivasi keinginan untuk berafiliasi dan menghindari konflik dengan orang yang dianggap penting tersebut.

d. Hubungan antara pengalaman pribadi dengan sikap wanita PUS melakukan skrining kanker serviks metode IVA

Pembuktian hipotesis adanya hubungan antara pengalaman pribadi dengan sikap wanita PUS melakukan skrining kanker serviks metode IVA, dilakukan uji hubungan dengan uji korelasi Chi-Square. Hasil uji korelasi didapatkan nilap $\mathrm{p}=$ 0,016 , dimana nilai $p<0,05$ yang menunjukkan ada hubungan antara pengalaman pribadi dengan sikap wanita PUS melakukan skrining kanker serviks metode IVA.

Tabel 4.8. Tabel silang hubungan pengalaman pribadi dengan sikap wanita PUS melakukan skrining kanker serviks metode IVA

\begin{tabular}{|c|l|c|c|l|}
\hline N & Sikap & \multicolumn{2}{|c|}{ Pengalaman pribadi } & To \\
\cline { 3 - 4 } & & $\begin{array}{c}\text { Tidak } \\
\text { berpengalaman }\end{array}$ & $\begin{array}{c}\text { Berpenga } \\
\text { laman }\end{array}$ & \\
\hline 1 & Negatif & 24 & 2 & 26 \\
\hline 2 & Positif & 15 & 9 & 24 \\
\hline & Total & 39 & 11 & 50 \\
\hline
\end{tabular}

Dari tabel 4.8 diatas dapat dilihat bahwa responden yang mempunyai sikap positif maupun sikap negatif terhadap pelaksanaan skrining kanker serviks metode IVA sebagian besar masih belum mempunyai pengalaman dalam melakukan skrining kanker serviks sebelumnya.

Skrining kanker serviks metode IVA masih merupakan metode untuk skrining kanker serviks yang tergolong baru. Skrining kanker serviks metode IVA mulai ditemukan pada tahun 2009 dengan kelompok sasaran yaitu wanita usia $30-50$ tahun yang sudah melakukan hubungan seksual aktif. Sedangkan di Kota Kediri pelayanan skrining kanker serviks metode IVA mulai dilaksanakan pada tahun 2010. Sehingga wajar jika masih banyak responden yang belum pernah melakukan skrining kanker serviks metode IVA. Karena memang tidak mudah untuk mengenalkan suatu metode baru kepada masyarakat.

Metode skrining kanker serviks dahulu menggunakan tes pap (pap smear). Kekurangan tes pap smear dibandingkan dengan tes IVA adalah tes pap smear biayanya mahal, tempat melakukan tes yang terbatas, hasil tidak dapat langsung dilihat karena harus dikirim ke laboratorium patologi anatomi ke Surabaya dan jadinya sekitar 1-2 bulan, sehingga 
banyak masyarakat yang enggan untuk melakukan tes pap smear.

Hal ini tidak sesuai dengan pendapat Middlebrook (1974) yang dikutip Azwar (2008) mengatakan tidak adanya pengalaman sama sekali dengan objek psikologis cenderung akan membentuk sikap negatif terhadap objek tersebut.

Sebagian besar responden memang belum mempunyai pengalaman melakukan skrining kanker serviks baik dengan tes pap smear maupun IVA. Namun begitu bukan berarti responden mempunyai sikap yang negatif terhadap skrining kanker serviks metode IVA. Dalam hal ini bukan hanya pengalaman pribadi saja yang berperan, tetapi pengalaman orang-orang terdekat terhadap skrining kanker serviks metode IVA juga turut berperan membentuk sikap yang positif pada responden juga adanya kesadaran yang tinggi dari responden tentang pentingnya kesehatan bagi dirinya.

Tabel 4.9. Tabel ringkasan hasil uji korelasi menggunakan $\mathrm{Chi}$ Square antara variabel bebas dan variabel terikat

\begin{tabular}{|l|l|l|l|}
\hline No & $\begin{array}{l}\text { Variabel } \\
\text { Bebas }\end{array}$ & $\begin{array}{l}\text { Nilai } \\
\mathrm{P}\end{array}$ & Hasil \\
\hline 1 & Pengetahuan & 0,001 & Berhubungan \\
\hline 2 & $\begin{array}{l}\text { Dukungan } \\
\text { keluarga }\end{array}$ & 0,001 & Berhubungan \\
\hline 3 & $\begin{array}{l}\text { Sumber } \\
\text { informasi }\end{array}$ & 0,001 & Berhubungan \\
\hline 4 & Pengalaman & 0,016 & Berhubungan \\
\hline
\end{tabular}

Pada tabel 4.9 diatas dapat dilihat bahwa semua variabel bebas pengetahuan, dukungan keluarga, sumber informasi dan pengalaman mempunyai hubungan dengan variabel terikat yaitu sikap wanita PUS melakukan skrining kanker serviks metode IVA.

Kemudian keempat variabel tersebut dilakukan analisis pengaruh secara multivariat bersama-sama untuk mengetahui besarnya pengaruh variabel bebas terhadap variabel terikat yaitu skrining kanker serviks metode IVA.

\section{Analisis multivariate}

Semua variabel bebas yang terdapat hubungan dengan variabel terikat yaitu pengetahuan, sumber informasi, dukungan keluarga dan pengalaman pribadi secara bersama-sama dimasukkan dalam perhitungan uji regresi logistik berganda, dengan hasil terdapat pada Tabel 4.10.

Tabel. 4.10 Ringkasan hasil analisis multivariat dengan uji regresi logistik

\begin{tabular}{|l|l|c|}
\hline No & Variabel & Nilai $\mathrm{p}$ \\
\hline 1 & Pengetahuan & 0,003 \\
\hline 2 & Dukungan keluarga & 0,053 \\
\hline 3 & Sumber informasi & 0,999 \\
\hline 4 & Pengalaman pribadi & 0,065 \\
\hline
\end{tabular}

Tabel 4.10 menunjukkan hasil analisis uji multivariat dengan memasukkan variabel bebas yang berhubungan dengan variabel terikat yaitu pengetahuan, dukungan keluarga, sumber informasi dan pengalaman secara bersama-sama menunjukkan bahwa hanya variabel pengetahuan saja yang berpengaruh secara signifikan terhadap variabel terikat sikap wanita PUS melakukan skrining kanker serviks metode IVA yaitu dengan nilai $p$ 0,003 .

Hal ini sesuai dengan pendapat Sunaryo (2004) bahwa Sikap adalah kecenderungan bertindak dari individu, berupa respon tertutup terhadap stimulus ataupun objek dan salah satu komponen yang membentuk sikap adalah pengetahuan.

Pengetahuan adalah merupakan hasil tahu dan ini terjadi setelah orang melakukan pengindraan terhadap suatu objek tertentu. Pengetahuan atau kognitif merupakan domain yang sangat penting dalam membentuk tindakan seseorang ( overt behavior ) (Soekidjo Notoatmodjo, 2003).

Responden yang sudah mengetahui tentang skrining kanker serviks metode IVA baik melalui penyuluhan yang dilakukan oleh petugas kesehatan maupun dari media massa (televisi, majalah, koran, radio, internet) cenderung mempunyai sikap yang positif terhadap skrining kanker serviks metode IVA. Hal ini disebabkan karena memang banyak sekali keuntungan 
dari skrining kanker serviks metode IVA diantaranya adalah tekniknya sederhana, dapat dilaksanakan di tempat pelayanan kesehatan yang mempunyai peralatan yang terbatas, dapat dilakukan oleh tenaga kesehatan yang sudah pernah mendapat pelatihan atau sosialisasi tentang skrining kanker serviks metode IVA, biayanya murah, hasil dapat langsung diperoleh dan jika ada kelainan dapat langsung di obati saat itu juga.

Bagi pasien yang hasil skrining kanker serviks metode IVA nya positif dapat dilakukan cryo therapi. Di Kota Kediri sudah terdapat 3 alat cryo therapi yaitu di Puskesmas Ngletih, Puskesmas Balowerti dan Puskesmas Pesantren II.

Pelayanan skrining kanker serviks metode IVA dapat dilaksanakan di semua tingkat pelayanan kesehatan baik di Puskesmas, Puskesmas Pembantu, Pos Kesehatan Kelurahan dan Bidan Praktek Mandiri (BPM) sehingga masyarakat mudah untuk mengakses pelayanan skrining kanker serviks metode IVA.

\section{Kesimpulan}

1. Ada hubungan antara pengetahuan dengan sikap wanita PUS melakukan skrining kanker serviks metode IVA di wilayah kerja Puskesmas Kota wilayah utara Kota Kediri

2. Ada hubungan antara media masa (sumber informasi) dengan sikap wanita PUS melakukan skrining kanker serviks metode IVA di wilayah kerja Puskesmas Kota wilayah utara Kota Kediri

3. Ada hubungan antara dukungan keluarga dengan sikap wanita PUS melakukan skrining kanker serviks metode IVA di wilayah kerja Puskesmas Kota wilayah utara Kota Kediri

4. Ada hubungan antara pengalaman pribadi dengan sikap wanita PUS melakukan skrining kanker serviks metode IVA di wilayah kerja Puskesmas Kota wilayah utara Kota Kediri

5. Faktor yang mempengaruhi sikap wanita PUS melakukan skrining kanker serviks metode IVA di wilayah kerja
Puskesmas Kota wilayah utara Kota Kediri adalah pengetahuan

\section{Saran}

1. Dinas Kesehatan Kota Kediri

a. Meningkatkan KIE tentang skrining kanker serviks metode IVA melalui media cetak seperti Koran, majalah

b. Meningkatkan KIE tentang skrining kanker serviks metode IVA melalui media elektronik seperti televisi, radio

c. Meningkatkan KIE tentang skrining kanker serviks metode IVA dengan memasang spanduk, penyebaran leaflet dll

2. Puskesmas Kota Wilayah Utara

a. Memberikan KIE tentang skrining kanker serviks metode IVA terutama kepada kelompok wanita PUS pada saat kegiatan Posyandu

b. Memasang spanduk tentang skrining kanker serviks metode IVA baik di Puskesmas maupun di Poskeskel

c. Membuat leaflet tentang skrining kanker serviks metode IVA untuk dibagikan ke semua pengunjung di Puskesmas maupun di Poskeskel

d. Membentuk petugas khusus untuk melakukan KIE tentang skrining kanker serviks metode IVA

\section{Daftar Pustaka}

Depkes RI. Buku Acuan Pencegahan Kanker Leher Rahim dan Kanker Payudara. Departemen Kesehatan. Jakarta. 2007

Kepmenkes RI Nomor 796/ Menkes/SK/VII/2010 tentang Pedoman Teknis Pengendalian Kanker Payudara dan Kanker Leher Rahim, Jakarta. 2010, http://www.hukor.depkes.go.id/up-laodkepmenkes/KMK/\%20No.\%20796\%20tt g\%kanker\%20rahim.pdf. diakses tanggal 4 November 2011

Moerdijat, TS dkk, Menggulirkan Sisitim Terbuka Pencegahan Kanker Serviks Di Indonesia,

http://www.rotayd3400.org/campur/penc egahan\%20kanker\%20serviks\%20di\%2 
Oindonesia.pdf.diakses tanggal 4 November 2011

Dinas Dan Informatika Provinsi Jawa Timur, Bahaya Kanker Serviks Mengintai, http://www.jatimprov.go.id/in dex.php?option $=$ comcontent $\&$ task $=$ view \&id=4008\&itemid $=2$, diakses tanggal 17 Oktober 2011

Suwiyoga,IK. Beberapa Masalah Pap Smear Sebagai Alat Diagnosis Dini Kanker Serviks Di Indonesia, http://www.ejournal.unud.ac.id/abstrak/p ap/pdf. diakses tanggal 4 November 2011.

Depkes RI. Modul Pelatihan Kanker Serviks dan Payudara.Departemen Kesehatan, Jakarta. 2007

Sjamsudin, S. Pencegahan dan Deteksi Dini Kanker Serviks. Cermin Dunia Kedokteran. 2001; 133

Kepmenkes RI Nomor 796/ Menkes/SK/VII/2010. Pedoman Teknis Pengendalian Kanker Payudara dan Kanker Leher Rahim, http://www.hukor.depkes.go.id/up-load kepmenkes/KMK/\%20No.\%20796\%20tt g\%20kanker\%20rahim.pdf , diakses tanggal 4 November 2011

Tapan, E. Kanker, Antioksidan dan Terapi Komplementer. PT. Elex Media Komputindo. Jakarta. 2005

Ramli, M dkk. Deteksi Dini Kanker. Fakultas Kedokteran Universitas Indonesia, Jakarta, 2002

Arikunto, S. Prosedur Penelitian, Rineka Cipta, Jakarta, 2002

Sugiyono, Statistik Untuk Penelitian dan Aplikasinya, Alfabeta, Bandung, 2006

Sudjana. Metode Statistika. Tarsito, Bandung, 2002

Azwar, S. Metode Penelitian, Pustaka Pelajar, Yogyakarta, 2003

Nurgiyantoro,B dkk. statistik Terapan Untuk Penelitian Ilmu-Ilmu Sosial. Gadjahmada University Press, Yogyakarta, 2004

Priyo, S. Basic Data Analysis For Health Research. Fakultas Kesehatan Masyarakat Universitas Indonesia, Jakarta, 2006
Sugiyono, Statistik Untuk Penelitian dan Aplikasinya, Alfabeta, Bandung, 2006

Rahmawan,A. Perkembangan Lanjutan Metode Skrining Kanker Serviks Dan Antisipasinya Dengan Vaksinasi Di Indonesia,

http://ahmadrahmawan.blogspot.co/2009 /10/perkembangan-lanjut-metode-

skrining.html, diakses tanggal 4 November 2011

Kepmenkes RI Nomor HK. 03.01/160/I/2010, Rencana Strategis Kementerian Kesehatan Tahun 2010 2014, Jakarta, 2010

PT.Pertamina (Persero) Corporate Website, Ibu Negara Mencanangkan Gerakan Perempuan Melawan Kanker Serviks, Pertamina BUMN Pertama Mendukung Upaya Pencegahan Kanker Serviks, http://www.pertamina.com/index.php/de tail/view/news-release/8502, diakses tanggal 11 Maret 2012

Nursalam; Pendekatan Praktis Metodologi Riset Keperawatan. CV. Sagung Seto, Jakarta, 2001

Robbins, Stephen P., Mary C. Management. Prentice Hail Inc, New Jersey, 1999

Heryanto, N; Pentingnya Landasan Filsafat Ilmu Pendidikan Bagi Pendidikan (Suatu Tinjauan Filsafat Sains). Institut Pertanian, Bogor, 2012 